\title{
10-years experience of dental root caries treatment in patients with gingival recession
}

\author{
L.N. Dedova ${ }^{1}$, O.V. Kandrukevich ${ }^{2}$, O.S. Gorodetska ${ }^{2}$, L.A. Denisov ${ }^{3}$ \\ ${ }^{1} \mathrm{MD}, \mathrm{PhD}$, DMSci, Professor, Belarusian State Medical University, Minsk, Belarus \\ ${ }^{2} \mathrm{MD}$, PhD, Associate Professor, Belarusian State Medical University, Minsk, Belarus \\ ${ }^{3} \mathrm{MD}, \mathrm{PhD}$, Associate Professor, Belarusian State Medical Academy of Porstgraduate Education, Minsk, Belarus
}

Summary. Based on the analysis of our own clinical experience, a concept of approaches to planning diagnostic, preventive and curative measures for patients with dental root caries and gingival recession was developed.

The aim of the research. To provide a rationale for the developed concept of approaches to planning diagnostic, preventive and curative measures for patients with dental root caries and gingival recession.

Objects and methods. Dental examination and treatment of more than 1082 subjects with dental root caries and gingival recession was performed. Registration and objective assessment of clinical condition were carried out based on the analysis of a survey data, clinical examination data and a series of objective parameters. Control examinations were carried out every 3 to 6 months. The effectiveness of diagnostic, preventive and curative measures was assessed according to good, satisfactory and unsatisfactory results achieved.

Results and discussion. A complex of methods for diagnosis and treatment of root caries in patients with gingival recession was developed, which made it possible to propose and designate a new classification and treatment method for this group of patients. Conclusion. Feasibility of the developed concept for planning a diagnostic, preventive and curative measures in patients with dental root caries and gingival recession is supported by good therapeutic results achieved in $97.7 \%$ of patients in short-term follow-up period, and by consistency of these results in long-term observation period in $96.3 \%$ of patients, thus providing a rationale for application of the proposed concept in practical health care.

\section{0-летний опыт мечения кариеса корня у пациентов с рецессией Аесны}

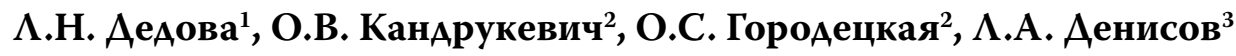 \\ ${ }^{1}$ А-р меА. наук, профессор, Беморусский государственный медицинский университет, Минск, Беларусь \\ ${ }^{2}$ канА. мед. наук, Аоцент, Белорусский госуАарственный медицинский университет, Минск, Беларусь \\ ${ }^{3}$ канА. меА. наук, доцент, Белорусская медицинская академия последипломного образования, Минск, Беларусь
}

Резюме. На основании Аанных анализа собственного клинического опыта сформировалась концепция в подходах к планированию диагностических и кечебно-профикактических мероприятий у пациентов с кариесом корня и рецессией десны. Цель исследования: обозначить целесообразность разработанной концепции в подходах кпланированию диагностических и мечебно-профикактических мероприятий у пациентов с кариесом корня и рецессией десны.

Объекты и методы исследования. Провели обследование и кечение более 1082 пациентов с кариесом корня зуба и рецессией десны. Учет и объективную оценку кминического состояния осуществляли на основании анализа данных опроса, клинического осмотра и изучения комплекса объективных показателей. Контрольные осмотры проводили кажАые 3-6 месяцев. Эффективность Аиагностических и мечебно-профилактических мероприятий считали по хорошим, УАов етворительным и неудовлетворительным результатам.

Результать исследования и их обсуждение. Разработан комплекс методов диагностики и мечения кариеса корня у пациентов с рецессией Аесны, который Аал возможность преАложить и обозначить новые кцассификацию и метоА мечения этой группы пациентов.

Заключение. Целесообразность разработанной концепции в подходах к планированию Аиагностических и мечебнопрофилактических мероприятий у пациентов с кариесом корня и рецессией десны подтверждается хорошими терапевтическими результатами в ближайшие сроки наблюдения у 97,7\% пациентов и их стабильностью в отАаленные сроки наблюдения у 96,3\% пациентов, что является основанием Аля применения преАложенной концепции в практическом зАравоохранении.

Ключевые слова: кариес корня зуба, рецессия десны, лечение 
D ental root caries - is a demineralization of dental root hard tissues, leading to their destruction as a result of multiple unfavourable factors interactions.

The prevalence of dental root caries in the Republic of Belarus is up to $40 \%[1,2]$.

Considering the issue of dental root caries, its growing prevalence among other dental diseases should be noted. Diagnosis, treatment, and prevention for such patients is of great practical importance, since this pathological process adversely affects the course of periodontal disease. In this regard, there is a need to introduce effective innovative strategies of choosing diagnostic, therapeutic, and preventive measures into dental practice, thus increasing the effectiveness of the therapy.

Based on the analysis of our own 10-years clinical experience, a concept of approaches to planning a diagnostic, preventive and $\mathrm{cu}$ rative measures for patients with dental root caries and gingival recession was developed $[3-10,13,17]$.

\section{THE AIM OF THE RESEARCH}

To provide a rationale for the developed concept of approaches to planning diagnostic, preventive and curative measures for patients with dental root caries and gingival recession.

\section{OBJECTS AND METHODS}

Dental examination and treatment of more than 1082 subjects with dental root caries and gingival recession was performed.

\section{The scheme of root caries development}

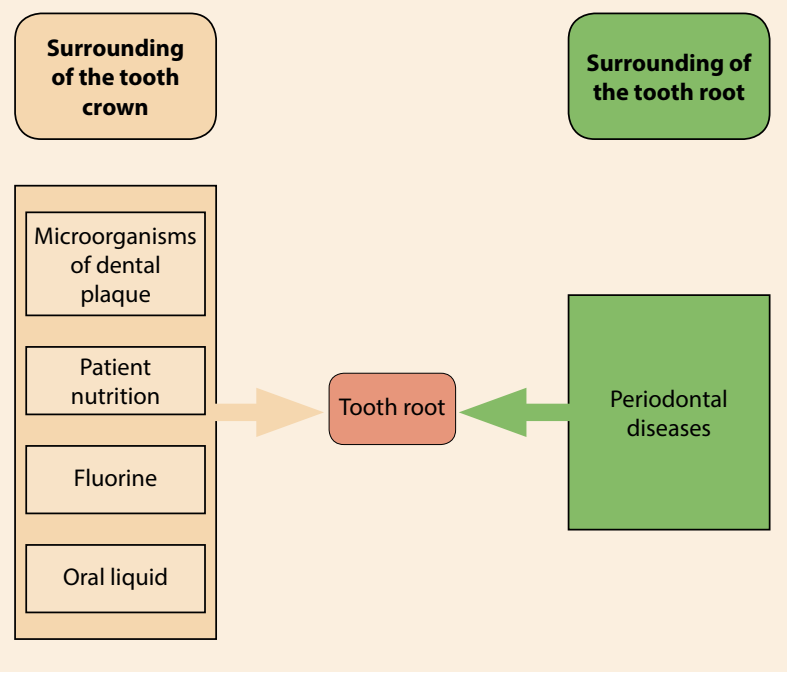

Fig. 1. The scheme of root caries development
Registration and objective assessment of clinical condition were carried out based on the analysis of a survey data, clinical examination data and a series of objective parameters. Control examinations were carried out every 3 to 6 months. The effectiveness of diagnostic, preventive and curative measures was assessed according to good, satisfactory and unsatisfactory results achieved.

\section{RESULTS AND DISCUSSION}

General principles of therapeutic and prophylactic measures in patients with dental root caries and gingival recession

- Monitoring of the dental crown and root surroundings

- Selection of the first and the second-line diagnostic methods

- Determination of the dental root caries clinical manifestations

- Selection of the individual approach strategy for differentiated treatment

- Systemic approach and effectiveness of maintenance therapy

\section{Monitoring of the dental crown and root} surroundings

The development of dental root caries depends on the state of oral cavity biological system, in which the surrounding of dental crown and surrounding of dental root are interrelated.

The influence of one or more factors forms surrounding of dental root, combined with cariogenic ones, leads to dental root caries (fig. 1). Thus, anatomical and topographical features of the dentoalveolar system, inflammatory-destructive or dystrophic processes in the periodontal tissues, trauma (mechanical, chemical, physical), the patient's age lead to gingival recession. Caries is developed on the bared surface of dental root under the influence of cariogenic factors. It should be noted that the demineralization of dental cementum and dentin of the dental root occurs at a $\mathrm{pH}$ equal to $6.2-$ $6.7[8,12,15,16,20]$.

\section{Selection of the first and the second line-} diagnostic methods

Diagnosis of dental root caries was carried out according to examination scheme for the dental patient.

The first-line diagnostic methods were used as the main and mandatory in the examination of the patient with dental root caries and gingival 
Table 1. Classification of dental root caries (L.N. Dedova, O.V. Kandrukevich, 2008, 2017)

\begin{tabular}{|c|c|c|c|c|}
\hline 1. Clinical course & 2. Depth & $\begin{array}{l}\text { 3. Dental hard } \\
\text { tissue }\end{array}$ & $\begin{array}{l}\text { 4. Topographic } \\
\text { surface of the root }\end{array}$ & 5. Localization \\
\hline $\begin{array}{l}\text { 1.1. Rapidly } \\
\text { progressive } \\
\text { 1.2. Chronic } \\
\text { 1.3. Remission } \\
\text { 1.4. Relapse }\end{array}$ & $\begin{array}{l}\text { 2.1. Spot without } \\
\text { dental hard tissues } \\
\text { lesion } \\
\text { 2.2. Lesion of the } \\
\text { dental hard tissues }\end{array}$ & $\begin{array}{l}\text { 3.1. Cementum } \\
\text { 3.2. Dentin }\end{array}$ & $\begin{array}{l}\text { 4.1. Vestibular } \\
\text { 4.2. Oral } \\
\text { 4.3. Approximal } \\
\text { 4.4. Circular } \\
\text { spreading }\end{array}$ & $\begin{array}{l}\text { 5.1. Supragingival } \\
\text { 5.2. Subgingival }\end{array}$ \\
\hline
\end{tabular}

recession for a preliminary diagnosis, which corresponded to the clinical protocols at the dental visit.

Second-line diagnostic methods were used for a detailed examination of the dental status and for objective evaluation of treatment results in patients with dental root caries. They included a complex of diagnostic tests, determining the condition of dental root hard tissues, hygiene of the oral cavity, periodontal tissues state and saliva.

Radiographic study of dental root caries included a parallel method, 'bite-wing' and orthopantomography for detection of hidden carious cavities on contact surfaces, periapical complications and evaluation of alveolar ridge condition $[5,8,11,16$, $18,19,23]$.

\section{Determination of dental root caries clinical manifestations}

Patients with dental root caries in some cases complained of a carious spot or cavity; short-term pain disappearing after the elimination of the causative factor. In some cases, complaints were absent or were associated with a patient's periodontal disease.

The level of pathological process development was determined in accordance with our proposed classification (L.N. Dedova, O.V. Kandrukevich, 2008, 2017) (table 1).

Topography and localization of carious lesion were evaluated during examination. The presence or loss of hard tissues at the root region was determined applying a probe to dental root surface, which enabled us to determine the depth of lesion, which consequently was categorized as a carious stain or carious defect. Dental root caries in the area of cementum below the cementodentinal junction was categorized as caries of cementum, and when the carious process was spreaded deep into the dentin it was categorized as a dentin caries of tooth root.
The clinical course of the carious process was categorized as following: chronic, rapidly progressive, relapse or remission.

In chronic dental root caries, the "chondroid" consistency of hard tissues was revealed, as well as the gently sloping edges of the carious cavity, without the tendency of rapid process development. Rapidly progres sive caries of the dental root was characterized as a process that developed over several months, which resulted in a softened consistency of hard tissues with sharp, uneven, pitted edges of the carious cavity. Remission of dental root caries was stated in the presence of carious lesions with a dense consistency of tissues, as well as with smooth, dense, gently sloping edges of the cavity and the absence of process progression. Relapse of dental root caries was stated in case of carious process, spreading along the edge of the filling previously placed on the surface of the dental root $[6,8,19]$.

\section{Selection of the individual approach} strategy for differentiated treatment

The use of all classification criteria in the diagnosis of dental root caries made it possible to reliably diagnose, predict and perform differentiated treatment in patients with dental root caries (fig. 2, 3).

After the diagnosis of dental root caries and after identification of possible risk factors, an individual treatment plan was created. The complex of treatment and prophylactic measures included initial, differentiated and maintenance treatment.

A complex method of local treatment of dental root caries in patients with gingival recession, was developed at the 3rd Department of Therapeutic Dentistry of the Belarusian State Medical University. It includes activities aimed at activating reconstructive processes in pathogenetic pathways of dental root caries and gingival recession (L.N. Dedova, O.V. Kandrukevich, 2009 - 2010) [10, 13, 17]. 


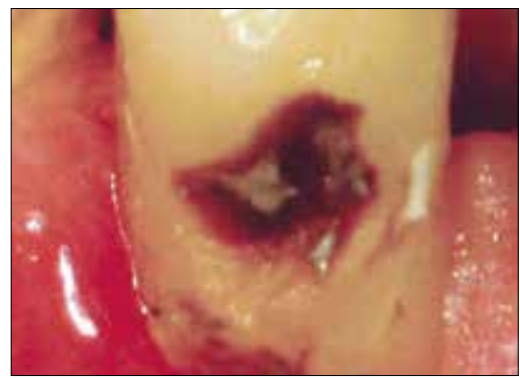

Fig. 2. Chronic supragingival carious spot without dentin defect on the vestibular surface of the root of tooth \# 3.3

\section{A complex of therapeutic and prophylactic measures for dental root caries in patients with gingival recession \\ Initial treatment: \\ - Hygienic measures \\ - Treatment of periodontal diseases (according to indications) \\ Differentiated treatment: \\ - Non-invasive or invasive \\ Maintenance treatment: \\ - Hygienic measures \\ - Treatment of periodontal diseases (according to indications) \\ - Remineralizing therapy}

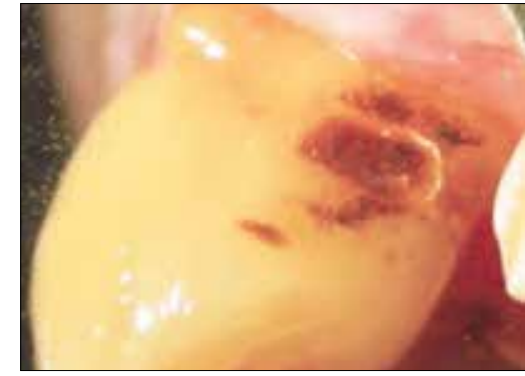

Fig. 3. Chronic supragingival cementum and dentin carious defect on the approximal surface of the root of tooth \# 2.3

Recommendations for hygienic oral care for patients with gingival recession and root caries included standard and vibrating methods of tooth brushing and using an irrigator [8]. Patients were recommended to use low abrasive fluoride-containing toothpastes (gels) combined with antiseptics. To clean the concave surfaces of the dental root, interdental brushes and single-beam toothbrushes were prescribed. In case of sensitive dentin, patients were recommended to use pastes containing potassium salts, hydroxyapatite, tricalcium phosphate, etc. Pastes, gels, rinses, containing lysozyme, lactoferrin, and saliva protein were proposed in case of reduced salivation.

The choice of periodontal diseases treatment strategy depended on the level of inflammatory-destructive or dystrophic processes in periodontium.

Differentiated treatment. Specific clinical manifestations of dental root caries and dental root and crown surrounding data were considered when choosing the treatment strategy (fig. 1, table 2).

Non-invasive treatment. In accordance with the principle of non-invasive treatment, remineralizing agents were used (table 3 ).

Table 2. Differentiated treatment of dental root caries in patients with gingival recession

\begin{tabular}{|l|l|}
\hline \multicolumn{1}{|c|}{ Clinical situation } & \multicolumn{1}{c}{ Treatment strategy } \\
\hline Spot without dental hard tissues defect & $\begin{array}{l}\text { Non-invasive: } \\
\text { risk factors elimination; } \\
\text { regular hygienic measures; } \\
\text { remineralizing agents; }\end{array}$ \\
\hline Carious dental root defect & $\begin{array}{l}\text { Invasive: } \\
\text { risk factors elimination; } \\
\text { regular hygienic measures; } \\
\text { preparation and filling; } \\
\text { remineralizing agents }\end{array}$ \\
\hline
\end{tabular}


Table 3. The sequence of applying medications for treating carious spots on the dental root

\begin{tabular}{|c|c|c|c|}
\hline № & Measure & Mechanism of action & Medication \\
\hline 1. & $\begin{array}{l}\mathrm{pH} \text { normalization } \\
\text { Cleaning the root surface }\end{array}$ & $\begin{array}{l}\text { - Buffer properties; } \\
\text { - Abrasive properties; }\end{array}$ & Sodium hydrogen carbonate \\
\hline 2. & $\begin{array}{l}\text { Decrease of oral microflora } \\
\text { pathogenicity }\end{array}$ & - Wide-spectrum antiseptic & Miramistin \\
\hline 3. & $\begin{array}{l}\text { Increase in the mineralization } \\
\text { of cementum and dentine with } \\
\text { calcium and phosphorus; }\end{array}$ & $\begin{array}{l}\text { - Substrate of phosphatases } \\
\text { involved in the mineralization of } \\
\text { tooth tissues; }\end{array}$ & Calcium glycerophosphate \\
\hline 4. & $\begin{array}{l}\text { Sealing of dentinal tubules, } \\
\text { demineralized cementum and } \\
\text { dentin microspaces; }\end{array}$ & $\begin{array}{l}\text { - Calcium and phosphorus in a } \\
\text { molar ratio of } 1.67 ; \\
\text { - Penetration of calcium and } \\
\text { phosphate ions into cementum } \\
\text { and dentin; } \\
\text { - Deep penetration of } \\
\text { nanoparticles into dental hard } \\
\text { tissues }\end{array}$ & Hydroxyapatite \\
\hline 5. & $\begin{array}{l}\text { Saturation of cementum and } \\
\text { dentin structures with fluorine; } \\
\text { Prolonged contact of medicinal } \\
\text { products with carious lesions of } \\
\text { dental root; }\end{array}$ & $\begin{array}{l}\text { - Releasing of fluoride ions; } \\
\text { - Sealing by methacrylate resins }\end{array}$ & Desensitizer, containing fluorine \\
\hline
\end{tabular}

Invasive treatment. Tooth preparation and filling were performed in case of dental root carious defects.

There was no carious cavity opening stage in most cases. An additional area was created on the oral surface of the dental root to access the approximal carious cavities of the dental root. The specific features of necrectomy were that in some cases it was carried out taking into account the small thickness of hard tissues in the area of dental root, and in other cases (for example, in rapidly progressive, multiple dental root caries) prophylactic removal of dental root hard tissues were also performed. The cavity was formed oval in shape or in combination with rectangular ledges, and then filled with glass ionomer cements (GIC), compomers.

Low abrasive burs with a rounded smooth ending, polishing discs, and brushes were used to finalize the fillings in dental root area $[6,8,14$, $21,22,24,25]$.

\section{Systemic approach and effectiveness of} maintenance therapy

At the stage of maintenance therapy individual treatment measures were used for patients with dental root caries and gingival recession, consistent with the principles of periodontology; and were reinforced with compulsory treatment of root surfaces using remineralizing agents at least every 3 months during the first year of follow-up. Further, the scope of treatment and prophylactic activities depended on the patient's assignment to the dispensary group $[3,7,9]$.

Results of clinical observation for patients with dental root caries and gingival recession revealed a significant therapeutic effect of our developed complex treatment method. It was evidenced by a statistically significant positive changes of the following parameters: dental root hard tissues mineralization (RI), dentin sensitivity (Complex index of differentiated tooth sensitivity, CIDTS), dental plaque index (PLI), gingival inflammation (GI), saliva (elasticity test, $\mathrm{pH}$, microscopy of dried drops); and also evidenced by the absence of a statistically significant decrease of dentogingival attachment in the long-term follow-up period, and by elongation of remission duration (according to case follow-up), compared to control groups [3, 10, 13].

\section{- CONCLUSION}

Feasibility of the developed concept for planning diagnostic, preventive and curative measures in patients with dental root caries and gingival recession is supported by good 
therapeutic results achieved in $97.7 \%$ of patients in short-term follow-up period, and by consistency of these results in long-term observation period in $96.3 \%$ of patients, thus providing a rationale for the application of the proposed concept in practical health care.

\section{References}

1. Dedova L.N., Denisova Ju.L., Kandrukevich O.V., Solomevich A.S., Rosenik N.I. Rasprostranennost' boleznej periodonta, kariesa kornja zuba, chuvstvitel'nosti dentina I zubocheljustnyh deformacij v Respublike Belarus' porezul'tatam obsledovanija naselenija v vozrastnyh gruppah 35-44, 45-54 i 55-64 goda [The prevalence of periodontal diseases, root caries, dentine sensitivity and dentoalveolar deformities in the Republic of Belarus based on the results of examining the population aged 35-44, 45-54 and 55-64 years]. Stomatolog. Minsk. - Stomatologist. Minsk. 2016, no. 1 (20), pp. 9-15.

2. Dedova L.N., Rubnikovich S.P., Denisova Ju.L., Kandrukevich O.V., Solomevich A.S., Rosenik N.I. Rasprostranennost' stomatologicheskih zabolevanija v Respublike Belarus' [The prevalence of dental diseases in the Republic of Belarus] Stomatologija. Jestetika. Innovacii. - Stomatology. Aesthetics. Innovation. 2017,Vol.1, no. 2, pp. 193-202.

3. Dedova L.N., Kandrukevich O.V. Jeffektivnost' lechenija kariesa kornja zuba [Effectiveness of caries treatment of tooth root]. Parodontologija. Periodontology, 2010, no. 1, pp. 67-68.

4. Dedova L.N., Kandrukevich O.V. Taktika lechenija karioznyh defektov tverdyh tkanej kornja zuba [Tactics of treatment of carious defects of hard tissues of the tooth root]. Stomatolog. Minsk. - Stomatologist. Minsk. 2012, no. 1 (4), pp. 76-81.

5. Dedova L.N., Kandrukevich O.V. Recessija desny: klinika, diagnostika. Planirovanie lechenija [Recession of the gums: a clinic, diagnostics. Treatment planning]. Stomatolog. Minsk. - Stomatologist. Minsk, 2014, no. 4 (15), pp. 93-101.

6. Dedova L.N., Kandrukevich O.V. Karies kornja zuba u pacientov s recessiej desny: klinicheskie projavlenija, diagnostika. Planirovanie lechenija [Caries of the tooth root in patients with gum recession: clinical manifestations, diagnosis. Treatment planning]. Stomatolog. Minsk. Stomatologist. Minsk, 2015. no. 1 (16), pp. 68-77.

7. Dedova L.N., Denisova Ju.L., Kandrukevich O.V., Solomevich A.S. Mnogoletnij opyt v provedenii podderzhivajushhej terapii u pacientov $\mathrm{s}$ boleznjami periodontal [Long-term experience in conducting maintenance therapy in patients with periodontal disease]. Parodontologija. Periodontology, 2016, no. 2 (79), pp. 70-75.

8. Dedova L.N., Denisova Ju.L., Kandrukevich O.V., Solomevich A.S. Terapevticheskaja stomatologija. Bolezni periodonta [Therapeutic dentistry. Periodontal disease]. Minsk: Jekoperspektiva. 2016, $268 \mathrm{p}$

9. Dedova L.N., Denisova Ju.L., Solomevich A.S. Mnogoletnij opyt v provedenii podderzhivajushhej terapii u pacientov s boleznjami periodonta [Long-term experience in conducting maintenance therapy in patients with periodontal disease]. Stomatolog. Minsk. - Stomatologist. Minsk, 2015, no. 4 (19), pp. 75-81

10. Dedova L.N., Kandrukevich O.V. Obosnovanie lekarstvennogo lechenija kariesa kornja zuba u pacientov s recessiej desny [Substantiation of medicinal treatment of tooth caries in patients with gingival recession (clinical and experimental study)]. Stomatolog. Minsk. - Stomatologist. Minsk, 2010, no. 1, pp. 7-13

11. Darevskij V.I., Solomevich A.S. Klinicheskaja ocenka jeffektivnosti lechenija chuvstvitel'nosti dentina u pacientov s okkljuzionnoj travmoj [Clinical evaluation of the effectiveness of treatment of dentin sensitivity in patients with occlusal trauma]. Innovacii v stomatologii: Materialy VI s'ezda stomatologov Belarusi. Minsk - Innovations in dentistry: Proceedings of the VI Congress of Dentists of Belarus. Minsk, 25.10 - 26.10. 2012, pp. 67-68.

12. Grudjanov A.I., Chepurkova O.A. Karies kornja: obzor literatury.[Caries root: a literature review]. Institut stomatologii. - Institute of Stomatology, 2003, no. 3, pp. 87-90.

13. Dedova L.N., Kandrukevich O.V. Kliniko-jeksperimental'noe obosnovanie metoda lekarstvennogo lechenija kariesa kornja zuba u pacientov s recessiej desny [Clinical and experimental substantiation of the method of drug treatment of caries of the tooth root in patients with gum recession] Medicinskij zhurnal. - Medical Journal, 2010, no. 2, pp. 50 - 55.

14. Dedova L.N., Solomevich A.S. Chuvstvitel'nost' dentina: sovremennye metody lechenija. [Sensitivity of dentin: modern methods of treatment]. Stomatolog. Minsk. - Stomatologist. Minsk. 2015, no. 2 (17), pp. 49-59.

15. Dedova L.N.,Gorodeckaja O.S. Sljuna: Sovremennyj vzgljad stomatologa [Saliva: The modern look of the dentist].Stomatolog. Minsk. Stomatologist. Minsk, 2011, no. 2 (3), pp. 15-18.

16. Dedova L.N., Kandrukevich O.V. Karies kornja zuba: teoreticheskie aspekty (Chast' 1) [Dental root caries: theoretical aspects (Part 1)]. Medicinskij zhurnal. - Medical Journal, 2007, no. 3, pp. 20-23.

17. Dedova L.N., Kandrukevich O.V., Pilipenko A.V. Vlijanie mestnogo vozdejstvija lekarstvennyh sredstv na mineralizaciju dentina kornja zuba $\mathrm{v}$ uslovijah jeksperimenta [Influence of local effects of drugs on the mineralization of dentin in the root of the tooth under experimental conditions]. Voennaja medicina. - Military medicine, 2009, no. 4, pp. 123-127.

18. Denisova Ju.L. Al'veoljarnyj indeks (AI) - novyj metod rentgenosteometrii v periodontologicheskoj praktike [Alveolar index (AI) - a new method of roentgenometry in periodontological practice]. Stomatolog. Minsk. - Stomatologist. Minsk, 2012, no. 3, pp. 24-28.

19. Laurisch L. Diagnostika I lechenie kariesa kornja [Diagnosis and treatment of root caries]. Kvintjessencija - Quintessence, 2004, no. 2, pp. 37-50.

20. Leus P.A. Biofil'm na poverhnosti zuba I karies [A biofilm on the tooth surface and caries]. M.: Izd. dom STBOOK. 2008, 87 p.

21. Maunt G.Dzh. Stomatologija minimal'nogo vmeshatel'stva: razvitie krioznogo porazhenija [Dentistry of minimal intervention: development of cryosacral lesion]. DentArt. 2005, no. 2, pp. 25-28.

22. Metody I programmy profilaktiki osnovnyh stomatologicheskih zabolevanij [Methods and programs for the prevention of major dental diseases]. VOZ. Zheneva. 1994, Teh. dokl. no. 713, 51 p.

23. Rubnikovich S.P. Lazerno-opticheskaja diagnostika boleznej periodontal iobosnovanie metodov ih lechenija [Laser-optical diagnostics of periodontal diseases and justification of methods of their treatment]. Stomatolog. Minsk. - Stomatologist. Minsk, 2012, no. 1, pp. 15.

24. Ftoridy I gigiena polosti rta [Fluorides and oral hygiene]. VOZ, Zheneva - WHO, Geneva. 1995, 55 p. (Serijateh. dokl. № 846).

25. Hel'vig Je., Klimek J., Attin T. Terapevticheskaja stomatologija [Therapeutic dentistry]. L'vov: GalDent. 1999, 409 p.

«21ST ANNUAL WORLD DENTAL SUMMIT» Аата проведения: 26-28 февраля 2018 Место проведения: Париж, Франция 